\title{
RISIKO DAN STRATEGI PENINGKATAN PRODUKSI UDANG VANNAMEI DI KECAMATAN BLANAKAN KABUPATEN SUBANG
}

\section{Risk and Improvement Strategy of Vannamei Shrimp Production In the Blanakan Sub-district Subang Regency}

\author{
*Kania Larasati Hartoyo dan Anna Fariyanti \\ Institut Pertanian Bogor \\ JI. Raya Dramaga, Kampus IPB Dramaga Bogor 16680 Jawa Barat, Indonesia \\ Diterima tanggal: 15 Maret 2018 Diterima setelah perbaikan: 21 Mei 2018 \\ Disetujui terbit: 18 Juni 2018 \\ "email: kaniakanialh@gmail.com
}

\begin{abstract}
ABSTRAK
Kecamatan Blanakan merupakan salah satu lokasi produksi udang vannamei di Jawa Barat dan menjadi salah satu lokasi penerapan progam revitalisasi tambak vannamei. Budi daya udang vannamei memiliki risiko produksi yang berasal dari faktor internal dan eksternal yang dapat terlihat pada fluktuasi produktivitas udang vannamei antar petambak. Tujuan dari penelitian ini yaitu menganalisis faktorfaktor yang memengaruhi produktivitas dan risiko produksi udang vannamei di Kecamatan Blanakan. Pemilihan responden dilakukan dengan metode purposive sampling sebanyak 70 petambak udang vannamei. Model Just and Pope digunakan untuk menganalisis risiko produksi. Hasil penelitian menunjukkan bahwa variabel-variabel yang dapat meningkatkan produktivitas udang vannamei yaitu pakan, kaporit, bakteri, dan dummy musim. Variabel benur merupakan faktor yang meningkatkan risiko sedangkan bakteri, solar, dan dummy musim merupakan faktor yang mengurangi risiko. Petambak perlu berhati-hati dalam menentukan padat tebar benur pada setiap musim serta mengontrol penggunaan tenaga kerja untuk meminimumkan risiko produksi. Peningkatan pendidikan dan pelatihan diperlukan untuk meningkatkan kemampuan tenaga kerja dalam budi daya udang vannamei.
\end{abstract}

Kata Kunci: risiko produksi; udang vannamei; Kabupaten Subang; just and pope; revitalisasi tambak udang

\begin{abstract}
Blanakan sub-district is one of the region selected by Ministry of Marine and Fisheries to implement shrimp farm revitalization program and become one of the biggest vannamei shrimp producer in West Java Province. However, vannamei shrimp aquaculture also deals with production risk from internal and external factors indicated from fluctuations of each farmers' productivity. The objectives of this research are to analyze the factors influencing vannamei shrimp productivity and production risk in Blanakan sub-district. Data were purposively sampled from 70 vannamei shrimp farmers. Just and Pope model was used in production risk analysis. The results show that variables that would increase vannamei shrimp productivity are shrimp feed, disinfectant, probiotic, and season dummy. Variable of shrimp fry is risk inducing factors, while probiotic, diesel fuel, and season dummy are risk reducing factors. Farmers need to be careful in determining shrimp fry density on every seasons and controlling labor usage to minimize production risk. Education and training improvement are necessary to increase labors' ability in vannamei shrimp aquaculture.
\end{abstract}

Keywords: production risk; vannamei shrimp; Blanakan; Just and Pope; shrimp farm revitalization

\section{PENDAHULUAN}

Perikanan merupakan salah satu sub sektor pertanian yang berkontribusi besar dalam pertumbuhan ekonomi Indonesia. Sub sektor perikanan juga merupakan penyumbang produk domestik bruto (PDB) terbesar ketiga setelah tanaman perkebunan dan tanaman pangan pada sektor pertanian dengan laju pertumbuhan sebesar 8,37\% pada tahun 2015 (KKP, 2016a). Menurut data Badan Pusat Statistik (2016a) produksi perikanan di Indonesia selalu meningkat setiap tahun. Pada tahun 2010 produksi perikanan di Indonesia sebesar 11.662 ribu ton dan meningkat menjadi 20.817 ribu 
ton pada tahun 2014. Selain itu, tren peningkatan konsumsi ikan tahun 2011-2015 sebesar 6,27\% dengan rata-rata konsumsi ikan sebesar 36,12 kg/ kapita/tahun (SIDATIK KKP, 2016b).

Sub sektor perikanan terdiri dari dua jenis, yaitu perikanan tangkap dan perikanan budi daya. Produksi perikanan budi daya di Indonesia pada tahun 2010 hingga 2014 selalu lebih tinggi dibandingkan produksi perikanan tangkap (BPS, 2016b). Subsektor perikanan juga memiliki 10 komoditas ekspor strategis, salah satunya udang vannamei. Provinsi Jawa Barat berada di peringkat ketiga produsen utama udang vannamei di Indonesia setelah Provinsi Nusa Tenggara Barat dan Jawa Timur. Jawa Barat berkontribusi sebesar 14,98 persen terhadap produksi udang vannamei nasional pada tahun 2015 (KKP, 2017). Produksi udang vannamei di Jawa Barat memiliki trend positif dari tahun ke tahun meskipun terdapat penurunan produksi yang terjadi pada tahun 2014 .

Kabupaten Subang merupakan salah satu wilayah dengan produksi udang vannamei terbesar di Jawa Barat. Luas lahan budi daya tambak potensial di Kabupaten Subang sekitar 14.300 hektar namun hanya sebagian kecil saja lahan tambak yang dimanfaatkan dengan rata-rata produksi udang sebesar 1.223,24 ton pada tahun 2012 (KKP, 2012). Besarnya potensi luas lahan budi daya tambak tersebut berimplikasi pada penetapan Kabupaten Subang, salah satunya Kecamatan Blanakan sebagai wilayah implementasi program revitalisasi tambak udang dan industrialisasi udang vannamei oleh Kementerian Kelautan dan Perikanan (KKP) yang dimulai pada akhir tahun 2012. Namun, Kecamatan Blanakan juga kerap mengalami penurunan produksi udang vannamei. Hal tersebut disebabkan oleh berbagai faktor, salah satunya faktor risiko produksi dalam budi daya udang vannamei (Tempo, 2014).

Adanya risiko produksi salah satunya diindikasikan dengan fluktuasi produktivitas yang cukup besar pada budi daya udang vannamei di Kecamatan Blanakan. Produktivitas udang vannamei di Kecamatan Blanakan pada periode April - Oktober 2013 sebesar 7,50 ton/hektar, meningkat menjadi 10,80 ton/hektar pada periode Oktober 2014 -April 2015, dan kembali menurun pada periode April - Oktober 2016 menjadi 9,53 ton/hektar (Divisi Marketing Global Shrimp Feed, 2016a). Selain itu juga terdapat fluktuasi mortality rate yang terjadi setiap siklus dan semakin mengindikasikan adanya risiko produksi udang vannamei di Kecamatan Blanakan. Mortality rate udang vannamei tertinggi di Kecamatan Blanakan yaitu sebesar $60 \%$ dan terendah sebesar $25 \%$ (Divisi Marketing Global Shrimp Feed, 2016b). Faktor-faktor risiko produksi dapat digolongkan menjadi dua, yaitu faktor risiko terkendali yang berasal dari variasi penggunaan input produksi dan faktor tidak terkendali yang berasal dari perubahan musim, penyakit, dan kualitas sumberdaya manusia. Hal tersebut juga didukung oleh penelitian Kharisma dan Manan (2012) yang menyatakan bahwa parameter fisika dan kimia mutu air yang tidak baik akibat penggunaan input produksi yang berlebihan serta kepadatan tebar yang terlalu tinggi menjadi penyebab utama melimpahnya populasi bakteri yang meningkatkan mortality rate udang vannamei. Adanya berbagai risiko produksi udang vannamei juga berakibat pada penurunan produksi dan pendapatan petambak. Oleh karena itu, penelitian ini penting dilakukan sebagai solusi bagi petambak dan pemerintah dalam upaya mitigasi untuk menentukan faktor produksi yang dapat bersifat meningkatkan maupun menurunkan risiko produksi. Berdasarkan hal tersebut, maka penelitian ini bertujuan untuk menganalisis faktor-faktor yang memengaruhi produktivitas udang vannamei di Kecamatan Blanakan dan menganalisis pengaruh faktor-faktor produksi terhadap risiko produksi udang vannamei di Kecamatan Blanakan.

\section{METODA PENELITIAN}

\section{Lokasi dan Waktu Penelitian}

Penelitian dilakukan di Kecamatan Blanakan, Kabupaten Subang. Pemilihan lokasi dilakukan secara sengaja (purposive) dengan mempertimbangkan bahwa Kecamatan Blanakan merupakan salah satu wilayah pelaksana program revitalisasi tambak udang vannamei dari Kementerian Kelautan dan Perikanan sejak akhir tahun 2012 dan juga menjadi salah satu sentra produksi udang vannamei terbesar di Kabupaten Subang. Pengambilan data dilakukan pada bulan April 2018.

\section{Jenis dan Sumber Data}

Data yang digunakan dalam penelitian ini adalah data primer dan data sekunder. Data primer diperoleh langsung melalui wawancara dengan para petambak, perangat desa, ketua kelompok tani, maupun pemerintah dinas setempat berupa data profil petambak, aktivitas usahatani, penggunaan input-input produksi, jumlah produksi, 
harga input dan output, serta biaya produksi lainnya. Sedangkan data sekunder diperoleh dari studi literatur dan bahan pustaka yang diperoleh dari berbagai publikasi dan instansi pemerintahan yang terkait berupa informasi umum mengenai perikanan budi daya, budi daya udang vannamei, produksi udang vannamei, serta informasi lain sebagai data pendukung dalam penelitian.

\section{Metode Sampling}

Sampel atau responden dari penelitian ini adalah petambak udang vannamei di Kecamatan Blanakan, khususnya di Desa Jayamukti dan Muara. Metode penentuan sampel yang digunakan adalah purposive sampling dengan kriteria petambak minimal telah melakukan Budi daya udang vannamei sejak tahun 2013 secara kontinu sejak program revitalisasi tambak udang vannamei dilaksanakan. Data yang digunakan merupakan data cross section dengan mempertimbangkan dua siklus Budi daya yaitu siklus ke-I (Oktober 2016 - April 2017) dan II (April - Oktober 2017). Data dua siklus produksi digunakan untuk mengetahui pengaruh musim terhadap risiko produksi udang vannamei. Jumlah sampel yang diambil sebanyak 70 orang karena tidak terdapat data mengenai jumlah populasi petambak udang vannamei di Kecamatan Blanakan. Menurut kaidah batas sentral (central limit theorem) untuk ukuran sampel yang cukup besar $(n \geq 30)$, rata-rata sampel terdistribusi di sekitar rata-rata populasi yang mendekati distribusi normal (Cooper and Emory, 1996).

\section{Metode Pengumpulan dan Analisis Data}

Pengumpulan data dilakukan dengan wawancara dan diskusi, pengamatan langsung pada lokasi penelitian, dan studi literatur. Penelitian ini menggunakan analisis kuantitatif statistik deskriptif dan inferensial. Analisis kuantitatif dengan model Just and Pope digunakan untuk menghitung risiko produksi udang vannamei.

\section{Model Risiko Produksi Just and Pope}

Model yang digunakan yaitu model risiko produksi Just and Pope yang digambarkan oleh fungsi produktivitas rata-rata dan fungsi varians produktivitas (Just and Pope, 1976). Bentuk fungsi yang digunakan dalam penelitian ini yaitu fungsi cobb-douglas karena merupakan model yang paling umum digunakan serta koefisien modelnya dapat diinterpretasikan dengan mudah. Fungsi cobbdouglas yang digunakan dalam fungsi produktivitas rata-rata dituliskan sebagai berikut:
Fungsi produktivitas rata-rata $[E[y]=f(X)]$ :

$$
\begin{aligned}
& \operatorname{Ln} Y_{i}=\alpha_{0}+\alpha_{1} \operatorname{Ln} X_{1 i}+\alpha_{2} \operatorname{Ln} X_{2 i}+\alpha_{3} \operatorname{Ln} X_{3 i}+\alpha \\
& { }_{4} \operatorname{Ln} X_{4 i}+\alpha_{5} \operatorname{Ln} X_{5 i}+\alpha_{6} \operatorname{Ln} X_{6 i}+\alpha_{7} \operatorname{LnX} X_{7 i}+ \\
& \alpha_{8} D_{1 i}+\varepsilon
\end{aligned}
$$

Variance produktivitas menunjukkan keragaman produktivitas yang dihasilkan setiap responden dan dapat diinterpretasikan sebagai gangguan heteroskedastisitas (Asche and Tveteras, 1999). Heteroskedastisitas menunjukkan bahwa variance error memiliki nilai yang berbeda-beda pada setiap observasi. Indikasi adanya risiko produksi dapat dilihat dari adanya fluktuasi produktivitas. Fluktuasi produktivitas ini menyebabkan data produksi sangat bervariasi sehingga dalam pengukuran risiko produksi diggunakan pendekatan nilai variance error.

Varians produktivitas:

$\sigma 2 Y i=(Y i-\bar{Y} i) 2$

Sedangkan untuk melihat pengaruh input produksi terhadap risiko produksi yaitu menggunakan fungsi varians produktivitas atau fungsi risiko produksi sebagai berikut:

Fungsi risiko produksi $[\mathrm{h}(\mathrm{X})]$ :

$\operatorname{Ln} \sigma_{Y i}^{2}=\beta_{0}+\beta_{1} \operatorname{Ln} X_{1 i}+\beta_{2} \operatorname{Ln} X_{2 i}+\beta_{3} \operatorname{Ln} X_{3 i}+$ $\beta_{4} \operatorname{Ln} X_{4 i}+\beta_{5} \operatorname{Ln} X_{5 i}+\beta_{6} \operatorname{Ln} X_{6 i}+\beta_{7} \operatorname{Ln} X_{7 i}+$ $\beta_{8} D_{1 i}+\varepsilon$

Keterangan/Remarks:

$Y_{i}=$ Produktivitas udang vannamei aktual $(\mathrm{kg} / \mathrm{ha}) /$ Actual vannamei shrimp productivity ( $\mathrm{kg} / \mathrm{ha})$

$\bar{Y}_{i}=$ Produktivitas udang vannamei rata-rata $(\mathrm{kg} /$ ha)/ Mean vannamei shrimp productivity ( $\mathrm{kg} / \mathrm{ha}$ )

$\mathrm{X}_{1}=$ Jumlah penggunaan benur per siklus (ekor/ ha)/ Quantity of shrimp fry per cycle (unit/ha)

$\mathrm{X}_{2}=$ Jumlah penggunaan pakan per siklus $(\mathrm{kg} /$ ha)/ Quantity of shrimp feed per cycle ( $\mathrm{kg} / \mathrm{ha}$ )

$\mathrm{X}_{3}=$ Jumlah penggunaan kaporit per siklus $(\mathrm{kg} /$ ha)/ Quantity of disinfectant per cycle ( $\mathrm{kg} / \mathrm{ha}$ )

$\mathrm{X}_{4}=$ Jumlah penggunaan bakteri per siklus (liter/ ha)/ Quantity of probiotic per cycle (liter/ha) 
$\mathrm{X}_{5}=$ Jumlah penggunaan kapur per siklus $(\mathrm{kg} / \mathrm{ha}) /$ Quantity of lime per cycle ( $\mathrm{kg} / \mathrm{ha}$ )

$\mathrm{X}_{6}=$ Jumlah penggunaan solar per siklus (liter/ ha)/ Quantity of diesel fuel per cycle (liter/ha)

$\mathrm{X}_{7}=$ Jumlah penggunaan tenaga kerja per siklus (HOK/ha)/ Quantity of labor per cycle (HOK/ha)

$\mathrm{D}_{1}=$ Dummy musim $\left(D_{1}=1\right.$ jika musim kemarau (siklus II April - Oktober 2017) dan $D_{1}=0$

jika musim hujan (siklus I Oktober 2016 April 2017))/ Season dummy $\left(D_{1}=1\right.$ if dry season (cycle II April - Oktober 2017) and $D_{1}$ $=0$ if rainy season (cycle I Oktober 2016 April 2017))

$\varepsilon=$ Unsur error/ error element

$\mathrm{i}=$ Petambak responden/ Respondent farmer

$\alpha_{0}=$ Konstanta/ constant

$\beta_{0}=$ Konstanta/ constant

$\alpha_{i}=$ Koefisien parameter dugaan input produksi udang vannamei $X_{1}, X_{2}, \ldots, X_{7} D_{1} /$ Parameter coefficient of vannamei shrimp production input estimation $X_{1}, X_{2}, \ldots, X_{7}, D_{1}$

$\beta_{\mathrm{i}}=$ Koefisien parameter dugaan input risiko udang vannamei $X_{1}, X_{2}, \ldots, X_{7} D_{1} /$ Parameter coefficient of vannamei shrimp risk input estimation $X_{1}, X_{2}, \ldots, X_{7}, D_{1}$

\section{HASIL DAN PEMBAHASAN}

\section{Penggunaan Input Budi Daya Udang Vannamei}

Budi daya udang vannamei secara intensif memiliki aturan yang sangat ketat terutama dalam penggunaan input sehingga mengharuskan petambak untuk mematuhi Standard Operational Procedure (SOP) budi daya yang ada. SOP yang menjadi acuan dalam penelitian ini bersumber dari KKP dan CP Prima. Ketidaksesuaian penggunaan input, baik mengurangi atau melebihi batas optimal pada SOP akan sangat mempengaruhi produktivitas udang vannamei. Berikut merupakan statistik penggunaan input, produktivitas, dan SOP budi daya udang vannamei yang ditampilkan pada Tabel 1.

Produktivitas rata-rata udang vannamei di Kecamatan Blanakan jauh lebih rendah dibandingkan dengan produktivitas rata-rata yang sesuai dengan SOP. Selain itu terdapat perbedaan yang sangat besar antara produktivitas terendah dan tertinggi udang vannamei di Kecamatan Blanakan yaitu sebesar 15.011,94 kilogram per hektar. Hal tersebut disebabkan oleh ketidaksesuaian penggunaan input budi daya dengan SOP yang ada. Penggunaan input budi daya udang vannamei oleh para petambak sampel di Kecamatan Blanakan cenderung lebih rendah dari penggunaan optimal.

Tabel 1. Penggunaan Input, Produktivitas, dan SOP Budi daya Udang Vannamei di Kecamatan Blanakan, Kabupaten Subang, 2017.

Table 1. Input Usage, Productivity, and SOP of Vannamei Shrimp Aquaculture in Blanakan Sub-district, Subang Regency, 2017.

\begin{tabular}{lrrrrr}
\hline \multicolumn{1}{c}{ Variabel/Variable } & \multicolumn{1}{c}{$\begin{array}{c}\text { Rata-rata/ } \\
\text { Mean }\end{array}$} & $\begin{array}{c}\text { Minimum/ } \\
\text { Minimum }\end{array}$ & $\begin{array}{c}\text { Maksimum/ } \\
\text { Maximum }\end{array}$ & $\begin{array}{c}\text { Std. Deviasi/ } \\
\text { Std. Deviation }\end{array}$ & \multicolumn{1}{c}{ SOP } \\
\hline $\begin{array}{l}\text { Produktivitas (kg/ha)/ } \\
\text { Productivity (kg/ha) }\end{array}$ & $8,941.69$ & $1,417.50$ & $16,429.44$ & $4,400.83$ & 15,000 \\
$\begin{array}{l}\text { Lahan (ha)/ Land (ha) } \\
\text { Benur (ekor/ha)/ }\end{array}$ & 1.61 & 0.50 & 7.00 & 1.22 & - \\
$\begin{array}{l}\text { Shrimp fry (unit/ha) } \\
\text { Pakan (kg/ha)/ }\end{array}$ & $12,285.91$ & $2,072.11$ & $26,865.96$ & $7,175.01$ & 24,000 \\
$\begin{array}{l}\text { Shrimp feed (kg/ha) } \\
\text { Kaporit (kg/ha)/ } \\
\text { Disinfectant (kg/ha) }\end{array}$ & 822.34 & 408.00 & $1,009.80$ & 122.45 & 1,020 \\
$\begin{array}{l}\text { Bakteri (liter/ha)/ } \\
\text { Probiotic (liter/ha) }\end{array}$ & 171.80 & 90.30 & 207.90 & 25.83 & 210 \\
$\begin{array}{l}\text { Kapur (kg/ha)/ } \\
\text { Lime (kg/ha) }\end{array}$ & $3,056.86$ & $1,600.00$ & $3,960.00$ & 569.20 & 4,000 \\
$\begin{array}{l}\text { Solar (liter/ha)/ } \\
\text { Diesel fuel (liter/ha) }\end{array}$ & $7,051.02$ & $2,184.57$ & $13,944.42$ & $2,555.32$ & 12,000 \\
$\begin{array}{l}\text { Tenaga kerja (HOK/ha)/ } \\
\text { Labor (HOK/ha) }\end{array}$ & 369.88 & 50.00 & 750.00 & 196.000000 & 783.75 \\
\hline
\end{tabular}

Sumber: Data Primer Diolah (2018)/Source: Primary Data Processed (2018) 
Rata-rata penggunaan benur di Kecamatan Blanakan cenderung sedikit lebih rendah dibandingkan dengan penggunaan optimal sesuai SOP. Hal tersebut dikarenakan wilayah Kecamatan Blanakan berada dekat dengan pantai utara Jawa dan memiliki riwayat terkena banjir besar sehingga para petambak mengurangi jumlah benur yang digunakan untuk mengantisipasi jumlah kerugian yang mungkin dihadapi. Selain itu terdapat beberapa lokasi tambak udang vannamei dengan kepadatan tinggi yang terkena penyakit sehingga para petambak mengurangi benur yang digunakan untuk meminimalisir masuknya penyakit.

Rata-rata penggunaan tenaga kerja di Kecamatan Blanakan yaitu sebesar 369,88 HOK per hektar juga masih lebih rendah dibandingkan dengan penggunaan optimal 783,75 HOK per hektar. Hal tersebut dikarenakan sebagian besar petambak tidak menggunakan teknisi tambak yang bertugas untuk mengontrol anak kolam yang bekerja seharian di tambak dan menentukan pemberian input yang sesuai dengan kebutuhan. Mayoritas petambak mengandalkan kemampuan diri sendiri dalam mengelola tambaknya dan juga berperan sebagai input tenaga kerja dalam keluarga.

\section{Faktor-Faktor yang Memengaruhi Produktivitas Udang Vannamei}

Nilai koefisien determinasi $\left(\mathrm{R}^{2}\right)$ menunjukkan bahwa 94,6 persen keragaman produktivitas udang vannamei di Kecamatan Blanakan dapat dijelaskan secara bersama-sama oleh faktor produksi yang dimasukkan dalam model, sedangkan sisanya sebesar 5,4 persen dijelaskan oleh faktor lain di luar model (Tabel 2). Hal tersebut menunjukkan bahwa variabel independen yang digunakan telah dapat menggambarkan variasi produktivitas udang vannamei.

Pada tahap awal, model melalui tahap pengujian model agar bersifat BLUE (Best Linear Unbiased Estimation). Hasil pengujian menunjukkan bahwa model fungsi produksi rata-rata udang vannamei di Kabupaten Subang terbebas dari masalah multikolinearitas, heteroskedastisitas, dan autokorelasi. Pengaruh faktor-faktor produksi terhadap produktivitas udang vannamei dijelaskan secara rinci sebagai berikut:

\section{Benur $\left(\mathbf{X}_{1}\right)$}

Koefisien input benur memiliki tanda negatif yang artinya penambahan input benur dapat menurunkan produktivitas udang vannamei namun tidak berpengaruh nyata karena nilai signifikansinya lebih dari taraf $\alpha=10$ persen. Pada usaha tani udang vannamei, jumlah padat tebar benur sangat memengaruhi survival rate udang vannamei. Padat tebar benur yang terlalu tinggi akan meningkatkan persaingan udang dalam memeroleh oksigen terlarut atau dissolved oxygen (DO) dan pakan dalam air. Apabila udang kekurangan DO dan pakan, maka udang lebih cepat stres dan survival rate akan turun, sehingga bobot

Tabel 2. Hasil Dugaan Fungsi Produktivitas Rata-rata Udang Vannamei di Kecamatan Blanakan, Kabupaten Subang, 2017.

Table 2. Estimation of Vannamei Shrimp Mean Productivity Function in Blanakan Sub-district, Subang Regency, 2017.

\begin{tabular}{lcccc}
\hline \multicolumn{1}{c}{ Variabel/Variable } & $\begin{array}{c}\text { Koefisien/ } \\
\text { Coefficient }\end{array}$ & $\begin{array}{c}\text { SE/ Standard } \\
\text { Error }\end{array}$ & $\begin{array}{c}\mathbf{t}-\text { hitung/ } \\
\boldsymbol{t}-\text { value }\end{array}$ & $\begin{array}{c}\text { Nilai Signifikansi } \\
\text { (prob.)/ Significancy } \\
\text { (prob.) }\end{array}$ \\
\hline Konstanta/ Constant & -1.0633 & 2.1758 & -0.4887 & 0.6259 \\
Ln Benur/ Ln Shrimp fry & -0.0643 & 0.1523 & -0.4225 & 0.6733 \\
Ln Pakan/ Ln Shrimp feed & 0.7167 & 0.0413 & 17.343 & $0.0000^{\mathrm{a}}$ \\
Ln Kaporit/ Ln Disinfectant & 0.3638 & 0.1363 & 2.6692 & $0.0086^{\mathrm{a}}$ \\
Ln Bakteri/ Ln Probiotic & 0.5309 & 0.1313 & 4.0437 & $0.0001^{\mathrm{a}}$ \\
Ln Kapur/ Ln Lime & -0.1596 & 0.1103 & -1.4467 & 0.1504 \\
Ln Solar/ Ln Diese/ Fuel & 0.0621 & 0.0525 & 1.1827 & 0.2391 \\
Ln Tenaga Kerja/ Ln Labor & -0.0317 & 0.0386 & -0.8205 & 0.4134 \\
Dummy Musim/ Season Dummy & 0.0650 & 0.0386 & 1.6856 & $0.0943^{\mathrm{c}}$ \\
\hline R-squared & 0.9464 & Adj R-sq & 0.9433 & \\
\hline
\end{tabular}

Sumber: Data Primer Diolah (2018)/Source: Primary Data Processed (2018)

Keterangan: a, b, c, dan d signifikan pada $\alpha=1 \%, 5 \%$, dan $10 \% /$ Remarks: $a, b, c$, and d are significant at $\alpha=1 \%, 5 \%$, and $10 \%$ 
maupun jumlah panen pun akan berkurang. Hal tersebut tentunya akan menurunkan produktivitas udang vannamei, namun masih dapat diatasi dengan menyesuaikan penggunaan input lainnya dengan jumlah benur yang digunakan. Kondisi tersebut menyebabkan variabel benur dapat menurunkan produktivitas udang vannamei namun tidak signifikan berpengaruh terhadap model. Hasil penelitian tersebut juga sesuai dengan penelitian yang dilakukan oleh dan Leung et al. (2000), Susilo (2007), Diatin et al. (2008), dan Sanchez-Zazueta dan Martinez-Cordero (2009).

\section{Pakan $\left(X_{2}\right)$}

Koefisien input pakan memiliki tanda positif yang artinya penambahan input pakan dapat meningkatkan produktivitas udang vannamei dan signifikan pada taraf $\alpha=1$ persen. Hasil estimasi variabel pakan yang berpengaruh positif terhadap produktivitas udang vannamei juga sejalan dengan penelitian Mustafa dan Ratnawati (2007), Diatin et al. (2008), dan Hartoyo (2017). Pakan merupakan sumber makanan utama bagi udang vannamei dan juga mengandung banyak zat nutrisi yang dibutuhkan bagi pertumbuhan udang vannamei.

Petambak sampel cenderung memberikan dosis pakan yang lebih rendah dibandingkan dengan SOP karena harga pakan udang vannamei yang relatif mahal sehingga petambak yang tidak memiliki cukup modal tidak dapat membeli pakan dalam jumlah yang banyak. Dosis pemberian pakan yang underfeeding dapat memperlambat pertumbuhan dan menurunkan daya tahan udang, sedangkan pemberian pakan yang overfeeding juga dapat memperburuk kualitas air tambak sehingga meningkatkan potensi terserang penyakit (Central Proteinaprima, 2013). Oleh karena itu, penggunaan pakan masih perlu ditingkatkan hingga dosis yang optimal sesuai SOP sehingga pertumbuhan dan produktivitas udang vannamei juga dapat ditingkatkan.

\section{Kaporit $\left(\mathbf{X}_{3}\right)$}

Hasil pendugaan fungsi produksi menunjukkan bahwa variabel kaporit merupakan variabel yang dapat meningkatkan produktivitas udang vannamei secara signifikan pada taraf $\alpha=1$ persen. Kaporit digunakan dalam tahap manajemen kualitas air pada persiapan tambak sebelum berlangsungnya usaha tani. Penggunaan kaporit bertujuan sebagai disinfektan yang dapat membunuh mikroorganisme dan virus yang menjadi carrier penyakit pada udang vannamei. Pada kondisi lapang, sekitar 35 persen petambak sampel di Kecamatan Blanakan cenderung tidak sabar dan tidak disiplin dalam melakukan manajemen kualitas air, sehingga lebih ingin cepat menebar benur.

Air tambak yang belum disterilisasi secara sempurna dalam tahap manajemen kualitas air masih membawa carrier penyakit yang dapat menurunkan survival rate udang vannamei, sehingga produktivitas udang vannamei pun dapat menurun. Pernyataan tersebut juga didukung oleh penelitian Cruz-Lacierda et al. (2008) bahwa kaporit dapat menjadi disinfektan yang dapat membantu mencegah terjangkitnya penyakit pada udang vannamei dan harus digunakan sesuai SOP. Penelitian yang dilakukan oleh Mustafa dan Ratnawati (2007), Mustafa et al. (2010), dan Hartoyo (2017) juga menemukan bahwa peningkatan penggunaan kaporit dapat meningkatkan produktivitas udang vannamei.

\section{Bakteri $\left(\mathbf{X}_{4}\right)$}

Nilai pendugaan parameter untuk variabel bakteri dalam pendugaan fungsi produksi bernilai positif dan signifikan pada taraf $\alpha=1$ persen. Secara umum, penggunaan bakteri bermanfaat dalam memproduksi senyawa penghambat berkembangnya bakteri patogen, menguraikan senyawa $\mathrm{H}_{2} \mathrm{~S}$ yang dihasilkan dari pakan yang tidak termakan, dan menguraikan bahan organik untuk menjaga kualitas air tambak. Semakin baik kualitas air tambak, maka survival rate dan produktivitas udang vannamei pun semakin meningkat.

Jumlah penggunaan bakteri oleh para petambak sampel masih lebih rendah dari dosis yang dianjurkan, bahkan juga terdapat petambak yang hanya menggunakan 90.3 liter bakteri per hektar padahal jumlah yang dianjurkan dalam SOP yaitu sebesar 210 liter per hektar. Berdasarkan hal tersebut, peningkatan penggunaan bakteri dalam usahatani udang vannamei dapat meningkatkan produktivitas udang vannamei. Hasil penelitian serupa juga dibuktikan oleh penelitian yang dilakukan oleh Mustafa dan Ratnawati (2007), Mustafa et al. (2010), dan Hartoyo (2017).

\section{$\operatorname{Kapur}\left(\mathbf{X}_{5}\right)$}

Koefisien parameter kapur memiliki tanda negatif, namun tidak signifikan karena memiliki nilai signifikansi yang melebihi taraf $\alpha=10$ 
persen. Hasil pendugaan koefisien kapur juga terdapat dalam penelitian Diatin et al. (2008) dan Mustafa et al. (2010) bahwa peningkatan penggunaan kapur dapat menurunkan produktivitas udang vannamei. Kapur yang biasa digunakan dalam usahatani udang vannamei yaitu kapur panas, dolomit, dan kaptan. Ketiga kapur tersebut digunakan dalam tahap pengapuran dasar tambak dalam persiapan tambak sebagai disinfektan dan meningkatkan $\mathrm{pH}$ tanah dan air.

Dosis penggunaan kapur tidaklah sama pada setiap tambak dan harus disesuaikan dengan karakteristik dan pHtanah dan air. Penggunaan kapur yang kurang dari dosis normal yang dianjurkan tidak terlalu berdampak buruk bagi pertumbuhan udang vannamei, sedangkan penggunaan jumlah kapur yang melebihi dosis atau tidak sesuai dengan $\mathrm{pH}$ tanah akan semakin mempercepat peningkatan $\mathrm{pH}$ tanah dan air sehingga menghambat pertumbuhan dan menurunkan survival rate udang vannamei. Serupa dengan penelitian yang dilakukan oleh Mustafa dan Ratnawati (2007) bahwa peningkatan penggunaan kapur berdampak negatif terhadap produktivitas udang vannamei, terutama pada air tambak yang telah memiliki $\mathrm{pH}$ yang tinggi. Hal tersebut juga dapat terjadi jika petambak tidak melakukan pengecekan $\mathrm{pH}$ tanah dan air sebelum pengaplikasian kapur.

\section{Solar $\left(\mathbf{X}_{6}\right)$}

Input solar dapat meningkatkan produktivitas udang vannamei namun tidak berpengaruh nyata karena nilai signifikansinya lebih dari taraf $\alpha=10$ persen. Serupa dengan penelitian Diatin et al. (2008) dan Ruiz-Velazco et al. (2010) bahwa peningkatan penggunaan input solar dapat meningkatkan produktivitas udang vannamei. Solar tidak secara langsung dapat meningkatkan produktivitas udang vannamei. Hal tersebut dikarenakan solar digunakan sebagai bahan bakar untuk menghidupkan kincir, pompa air, dan genset. Kincir berperan sebagai aerator dan mendistribusikan pakan keseluruh sudut tambak dan pompa digunakan untuk mengeluarkan air yang kotor dan mengisi kembali air yang sudah disterilkan ke setiap petakan tambak. Penggunaan jumlah kincir yang sesuai dapat meningkatkan tingkat DO dalam air dan pakan yang termakan udang vannamei sehingga pertumbuhan udang pun meningkat. Oleh karena itu, penggunaan jumlah solar yang sesuai secara tidak langsung dapat meningkatkan produktivitas udang vannamei.

\section{Tenaga Kerja $\left(X_{7}\right)$}

Penambahan input tenaga kerja dapat menurunkan produktivitas udang vannamei namun tidak berpengaruh nyata karena nilai signifikansinya lebih dari taraf $\alpha=10$ persen. Sekitar 82 persen petambak responden hanya menggunakan tenaga kerja berupa anak kolam yang mayoritas memiliki tingkat pendidikan SD dan SMP. Tingkat pendidikan anak kolam tersebut tergolong rendah dan sebagian besar anak kolam juga tidak memiliki pengalaman dan kemampuan usahatani udang vannamei. Oleh karena itu, penambahan tenaga kerja tersebut justru akan menurunkan produktivitas udang vannamei karena tidak memiliki kemampuan dalam usahatani udang vannamei. Namun hal tersebut masih dapat diimbangi dengan peningkatan manajemen usahatani oleh petambak tersebut sehingga penambahan input tenaga kerja tidak secara signifikan menurunkan produktivitas udang vannamei. Hasil dugaan serupa juga terdapat pada penelitian yang dilakukan oleh Saptana (2011) dan Vinanda (2016).

\section{$\operatorname{Musim}\left(D_{1}\right)$}

Nilai koefisien parameter dugaan untuk variabel dummy musim yaitu 0.0650 yang signifikan pada $\alpha=10$ persen. Hal tersebut menunjukkan bahwa produktivitas udang vannamei pada siklus II (musim kemarau) lebih tinggi dibandingkan dengan siklus I (musim hujan). Hasil penelitian yang sama juga terdapat pada penelitian yang dilakukan oleh Saptana (2011), Umiliana et al. (2016), Hartoyo (2017), dan Apriana (2017).

Berdasarkan kondisi di lapang, para petambak lebih menyukai melakukan budi daya udang vannamei pada musim kemarau karena suhu dan cuaca yang lebih stabil. Kestabilan tersebut membuat udang vannamei hidup normal (tidak stres), sehingga peningkatan penggunaan input-input produksi pada kondisi normal dapat meningkatkan produktivitas udang vannamei. Rata-rata produktivitas udang vannamei para petambak sampel di Kecamatan Blanakan pada musim hujan sebesar 6395.55 kilogram per hektar, sedangkan pada musim kemarau sebesar 11487.83 kilogram per hektar. Data tersebut membuktikan bahwa produktivitas udang vannamei pada musim kemarau jauh lebih tinggi daripada musim hujan dan sesuai 
dengan hasil koefisien parameter dugaan variabel dummy musim.

\section{Faktor-Faktor yang Memengaruhi Risiko Produksi Udang Vannamei}

Nilai $R^{2}$ pada Tabel 3 menunjukkan bahwa 19.58 persen variance produktivitas udang vannamei dapat dijelaskan oleh faktor produksi yang dimasukkan dalam model. Nilai koefisien determinasi fungsi risiko produksi tersebut relatif kecil dan serupa dengan penelitian yang dilakukan oleh Fanani (2015), Vinanda (2016), dan Apriana (2017). Model estimasi fungsi risiko produksi diperoleh melalui beberapa tahap estimasi sehingga nilai koefisien determinasinya cenderung rendah (Walter et al., 2004). Meskipun nilai koefisien determinasi relatif kecil, namun model tersebut sudah cukup baik menjelaskan sifat dan pengaruh penggunaan input terhadap produksi dan risiko produksi terutama dalam hal tanda (sign) dari setiap koefisien input produksi dalam model. Pengaruh faktor-faktor produksi terhadap variance produktivitas udang vannamei dijelaskan secara rinci sebagai berikut:

\section{Benur $\left(\mathbf{X}_{1}\right)$}

Input benur merupakan input yang dapat meningkatkan risiko produksi (risk inducing factor) dan berpengaruh nyata pada taraf $\alpha=5$ persen. Hasil estimasi fungsi risiko produksi ini juga didukung oleh hasil estimasi fungsi produksinya bahwa penambahan input benur dapat menurunkan produktivitas udang vannamei.

Setiap lahan tambak di suatu wilayah memiliki daya dukung lingkungan yang berbedabeda. Apabila penggunaan benur tidak sesuai dengan jumlah yang ditentukan terutama melebihi SOP dan daya dukung lingkungannya, maka persaingan udang dalam mendapatkan tempat hidup, oksigen terlarut, pakan, dan nutrisi mikro lainnya pun semakin tinggi. Persaingan yang ketat membuat udang lebih cepat stres sehingga daya tahannya pun semakin menurun. Kondisi tersebut secara langsung meningkatkan risiko produksi udang vannamei. Hasil yang sama juga terdapat dalam penelitian Leung et al. (2000), Susilo (2007), Diatin et al. (2008), dan Sanchez-Zazueta dan Martinez-Cordero (2009). Penggunaan benur yang tidak berlebihan menjadi salah satu upaya yang dapat dilakukan untuk mengurangi dampak risiko serangan penyakit (Sanchez-Zazueta dan Martinez-Cordero, 2009).

\section{Pakan $\left(\mathrm{X}_{2}\right)$}

Koefisien input pakan bertanda negatif yang artinya penggunaan input pakan yang tepat waktu dan tepat jumlah dapat menurunkan risiko produksi udang vannamei sehingga pakan tergolong dalam risk reducing factor. Hasil estimasi

Tabel 3. Hasil Dugaan Fungsi Risiko Produksi Udang Vannamei di Kecamatan Blanakan, Kabupaten Subang, 2017.

Table 3. Estimation of Vannamei Shrimp Production Risk Function in Blanakan Sub-district, Subang Regency, 2017.

\begin{tabular}{lcccc}
\hline \multicolumn{1}{c}{$\begin{array}{c}\text { Variabel/ } \\
\text { Variable }\end{array}$} & $\begin{array}{c}\text { Koefisien/ } \\
\text { Coefficient }\end{array}$ & $\begin{array}{c}\text { SE/ } \\
\text { Standard } \\
\text { Error }\end{array}$ & $\begin{array}{c}\mathbf{t}-\text { hitung/ } \\
\boldsymbol{t}-\text { value }\end{array}$ & $\begin{array}{c}\text { Nilai Signifikansi (prob.)/ } \\
\text { Significancy (prob.) }\end{array}$ \\
\hline Konstanta/ Constant & -31.921 & 21.006 & -1.5196 & 0.1310 \\
Ln Benur/ Ln Shrimp fry & 3.4141 & 1.4701 & 2.3224 & $0.0218^{\mathrm{b}}$ \\
Ln Pakan/ Ln Shrimp feed & -0.6197 & 0.3989 & -1.5532 & 0.1228 \\
Ln Kaporit/ Ln Disinfectant & 0.2579 & 1.3157 & 0.1961 & 0.8449 \\
Ln Bakteri/ Ln Probiotic & -3.5068 & 1.2677 & -2.7662 & $0.0065^{\mathrm{a}}$ \\
Ln Kapur/ Ln Lime & 1.3332 & 1.0649 & 1.2519 & 0.2128 \\
Ln Solar/ Ln Diesel Fuel & -1.0993 & 0.5066 & 2.1702 & $0.0318^{\mathrm{b}}$ \\
Ln Tenaga Kerja/ Ln Labor & 0.5866 & 0.3725 & 1.5746 & 0.1178 \\
Dummy Musim/ Season Dummy & -0.8251 & 0.3723 & -2.2161 & $0.0284^{\mathrm{b}}$ \\
\hline
\end{tabular}

\begin{tabular}{llll}
\hline R-squared & $0.1958 \quad$ Adj R-sq & 0.1467 \\
\hline
\end{tabular}

Sumber: Data Primer Diolah (2018)/Source: Primary Data Processed (2018)

Keterangan: $a, b, c$, dan d signifikan pada $\alpha=1 \%, 5 \%$, dan 10\%/Remarks: $a, b, c$, and $d$ are significant at $\alpha=1 \%$, $5 \%$, and $10 \%$ 
fungsi risiko produksi ini juga didukung oleh hasil estimasi fungsi produksinya bahwa penambahan input pakan dapat meningkatkan produktivitas udang vannamei.

Rata-rata penggunaan pakan para petambak sampel pada kedua siklus hanya sebesar 12 285.91 kilogram per hektar. Jumlah tersebut masih jauh dibandingkan dengan SOP yang dianjurkan sebesar 24 kilogram per hektar. Pemberian pakan yang baik haruslah sesuai dengan SOP yang sesuai dengan umur dan berat udang. Pemberian pakan yang underfeeding dapat memperlambat pertumbuhan udang dan menurunkan daya tahan udang vannamei. Pertumbuhan udang yang lambat dapat menurunkan bobot panen udang vannamei, sedangkan turunnya daya tahan udang dapat meningkatkan peluang terkena serangan penyakit sehingga survival rate akan turun. Hasil penelitian tersebut juga sesuai dengan penelitian Mustafa dan Ratnawati (2007), Diatin et al. (2008), dan Hartoyo (2017).

\section{Kaporit $\left(\mathbf{X}_{3}\right)$}

Hasil pendugaan fungsi risiko produksi menunjukkan bahwa variabel kaporit merupakan variabel yang dapat meningkatkan risiko produksi udang vannamei (risk inducing factor) namun tidak berpengaruh nyata karena nilai signifikansinya lebih dari taraf $\alpha=10$ persen. Meskipun rata-rata penggunaan kaporit petambak sampel di Kecamatan Blanakan masih sedikit lebih rendah dari dosis yang dianjurkan, namun penggunaan kaporit yang berlebihan memiliki efek samping yang buruk dalam usahatani udang vannamei.

Penggunaan kaporit sebagai tindakan kuratif harus sesuai dengan kondisi air. Proses oksidasi kaporit yang tidak sempurna dapat merubah kaporit menjadi senyawa yang mematikan udang vannamei. Dosis penggunaan kaporit yang tidak tepat juga dapat menurunkan daya dukung lingkungan dengan mematikan mikroorganisme, bakteri baik, dan plankton dalam air yang berguna bagi pertumbuhan udang vannamei. Hasil estimasi variabel kaporit yang dapat meningkatkan risiko produksi juga serupa dengan penelitian yang dilakukan oleh Diatin et al. (2008).

\section{Bakteri $\left(\mathbf{X}_{4}\right)$}

Nilai pendugaan parameter untuk variabel bakteri dalam pendugaan fungsi produksi bernilai negatif dan signifikan pada taraf $\alpha=1$ persen. Hal tersebut menunjukkan bahwa bakteri merupakan input yang dapat menurunkan risiko produksi (risk reducing factor). Hasil pendugaan parameter bakteri tersebut juga sesuai dengan estimasi fungsi produksi bahwa peningkatan penggunaan bakteri dapat meningkatkan produktivitas udang vannamei. Kesamaan hasil juga terdapat dalam penelitian Mustafa dan Ratnawati (2007) dan Mustafa et al. (2010).

Penggunaan bakteri sangatlah penting dalam usaha tani udang vannamei karena merupakan bagian dari manajemen kulitas air dalam SOP usaha tani udang vannamei. Kekurangan penggunaan bakteri akan menyebabkan timbunan bahan organik yang tinggi sehingga bakteri vibrio akan meningkat. Hal tersebut akhirnya dapat menurunkan kualitas air tambak dan menghambat pertumbuhan udang vannamei serta memicu penyebaran penyakit. Namun hasil penelitian berbeda terdapat pada penelitian Diatin et al. (2008) karena dosis penggunaan bakteri sudah melebihi dosis yang dianjurkan sehingga dapat meningkatkan risiko produksi.

\section{$\operatorname{Kapur}\left(\mathbf{X}_{5}\right)$}

Koefisien parameter kapur memiliki tanda positif namun tidak signifikan terhadap model fungsi risiko produksi. Kapur bersifat risk inducing factor yaitu input yang dapat meningkatkan risiko produksi. Kapurmerupakan salah satu input produksi yang penggunaannya bersifat kuratif. Meskipun penggunaan kapur oleh petambak responden masih kurang dari dosis yang dianjurkan, namun penggunaannya juga perlu disesuaikan dengan kondisi tanah dan air.

Apabila kondisi tanah dan air sudah normal, maka penggunaan kapur perlu dikurangi. Kapur memiliki sifat panas yang berfungsi sebagai disinfektan dan menaikkan $\mathrm{pH}$ air dan tanah, sehingga penggunaanya perlu diperhatikan dengan baik. Dosis penggunaan kapur yang tidak sesuai dapat menyebabkan plankton drop dan mematikan bakteri baik. Ukuran kapur yang halus akan lama terapung sehingga menghalangi intensitas sinar matahari yang masuk ke dalam air. Kondisi tersebut dapat dengan langsung menurunkan survival rate udang vannamei. Hasil dugaan input kapur sebagai risk inducing factor juga terdapat pada penelitian yang dilakukan oleh Mustafa dan Ratnawati (2007) dan Hartoyo (2017). Perbedaan hasil terdapat pada penelitian Mustafa et al. (2010) bahwa input kapur dapat meningkatkan produktivitas udang vannamei. 


\section{Solar $\left(\mathbf{X}_{6}\right)$}

Solar merupakan risk reducing factor karena memiliki tanda koefisien yang negatif dan dapat menurunkan risiko produksi udang vannamei secara signifikan pada taraf $\alpha=5$ persen. Hasil dugaan tersebut sesuai dengan estimasi fungsi produksi bahwa input solat dapat meningkatkan produktivitas udang vannamei. Kesesuaian hasil penelitian juga terdapat pada penelitian Diatin et al. (2008) dan Ruiz-Velazco et al. (2010). Solar digunakan sebagai salah satu sumber energi selain listrik yang digunakan untuk menyalakan kincir, pompa, dan genset. Petambak harus menggunakan solar sesuai dengan jumlah yang dianjurkan dan bahkan mempersiapkan jumlah dari yang dianjurkan.

Penggunaan solar yang sesuai berarti jumlah kincir dan pompa untuk manajemen kualitas air dan dasar tambak juga sesuai sehingga usahatani dijalankan sesuai dengan SOP. Jika jumlah kincir yang dinyalakan sesuai, maka pakan dapat terdistribusi ke seluruh bagian tambak sehingga semua udang dapat makan secara merata. Kincir juga memengaruhi jumlah oksigen terlarut dalam air karena berfungsi sebagai aerator, sedangkan penggunaan pompa yang sesuai berarti kualitas air tambaknya pun selalu baik untuk pertumbuhan udang. Penggunaan solar yang kurang dapat menghambat fungsi dari kincir dan pompa sehingga pertumbuhan dan survival rate akan menurun.

\section{Tenaga Kerja $\left(\mathbf{X}_{7}\right)$}

Input tenaga kerja dapat meningkatkan risiko produksi udang vannamei namun tidak signifikan karena lebih dari taraf $\alpha=10$ persen. Oleh karena itu, input tenaga kerja merupakan risk inducing factor. Hal ini terjadi karena usahatani udang vannamei merupakan usahatani yang telah memiliki SOP dalam menjalankan setiap tahapannya. Dibutuhkan tenaga kerja berupa anak kolam yang terampil dan memiliki pengalaman yang banyak dalam usahatani udang vannamei.

Pada daerah penelitian, sebagian besar anak kolam yang digunakan petambak merupakan warga sekitar yang didominasi hanya memiliki tingkat pendidikan setaraf SD dan SMP serta tidak memiliki keterampilan usahatani udang vannamei sebelumnya sehingga hanya mengandalkan instruksi petambak. Apabila instruksi petambak tidak dilakukan secara mendetail dan baik, maka usahatani akan tidak sesuai dengan SOP dan produktivitasnya dapat menurun. Jumlah penggunaan anak kolam pada daerah penelitian juga sudah sesuai dengan yang dianjurkan, sehingga apabila melebihi jumlahnya maka petambak akan merasa kesulitan dalam mengontrolnya dan juga merugikan karena biaya tenaga kerja yang tinggi. Hasil estimasi variabel tenaga kerja yang meningkatkan risiko produksi juga terdapat pada penelitian Fariyanti (2008), Fanani (2015), Vinanda (2016), dan Hartoyo (2017).

\section{$\operatorname{Musim}\left(D_{1}\right)$}

Nilai koefisien parameter dugaan untuk variabel dummy musim yaitu -0.8251 yang signifikan pada $\alpha=5$ persen. Hal tersebut menunjukkan bahwa musim kemarau merupakan faktor yang menurunkan risiko produksi (risk reducing factor). Musim sangat berpengaruh dalam tahap persiapan tambak dan proses usahatani udang vannamei. Musim kemarau yang memiliki suhu dan curah hujan yang tidak banyak dan cenderung stabil dapat menstabilkan kualitas air dan daya dukung lingkungan tambak. Keadaan yang stabil tersebut membuat udang tidak cepat stres sehingga daya tahan udang pun meningkat. Akibatnya pertumbuhan udang juga tidak terganggu dan survival rate tetap stabil. Pada penelitian Umiliana et al. (2016) menunjukkan bahwa salinitas rendah yang dapat terjadi pada musim hujan dapat meningkatkan risiko terkena serangan penyakit pada udang vannamei. Penelitian Saptana (2011), Hartoyo (2017), dan Apriana (2017) juga menyatakan bahwa musim kemarau merupakan faktor yang menurunkan risiko (risk reducing factor).

\section{KESIMPULAN DAN IMPLIKASI KEBIJAKAN}

\section{Kesimpulan}

Berdasarkan hasil dan pembahasan di atas, dapat disimpulkan bahwa faktor-faktor produksi yang berpengaruh positif terhadap produktivitas udang vannamei, yaitu pakan, kaporit, bakteri, solar, dan musim, sedangkan faktor produksi benur, kapur, dan tenaga kerja berpengaruh negatif terhadap produktivitas udang vannamei. Namun variabel benur, kapur, solar, dan tenaga kerja tidak berpengaruh nyata terhadap produktivitas udang vannamei. Faktor produksi yang merupakan faktor yang meningkatkan risiko (risk inducing factors) pada budi daya udang vannamei yaitu benur, sedangkan faktor produksi 
yang merupakan faktor yang mengurangi risiko (risk reducing factors) yaitu bakteri, solar, dan dummy musim.

\section{Implikasi Kebijakan}

Petambak perlu berhati-hati dalam menentukan padat tebar benur yang juga perlu disesuaikan dengan kondisi musim. Dari sisi kualitas tenaga kerja, diperlukan adanya peningkatan pendidikan, pengetahuan, dan kemampuan teknis dalam melakukan Budi daya udang vannamei melalui pemberian berbagai pelatihan informal kepada para tenaga kerja khususnya anak kolam. Penambahan tenaga kerja dapat dilakukan dengan merekrut teknisi tambak untuk mengontrol teknis Budi daya agar sesuai SOP budi daya udang vannamei. Para petambak udang vannamei di Kabupaten Subang khususnya Kecamatan Blanakan juga masih memerlukan pendampingan agar proses budi daya dan penggunaan input produksinya sesuai dengan SOP sehingga dapat meminimalisir adanya risiko produksi dan meningkatkan produktivitas udang vannamei.

\section{UCAPAN TERIMA KASIH}

Ucapan terima kasih ditujukan kepada Bapak Nono S. selaku Camat di Kecamatan Blanakan, serta Bapak Ispadi, Bapak Charka, dan para responden petambak udang vannamei lainnya di Desa Muara dan Desa Jaya Mukti, Kecamatan Blanakan, Kabupaten Subang yang telah memberikan informasi sangat lengkap.

\section{DAFTAR PUSTAKA}

Apriana, N. 2017. Analisis Risiko Produksi Petani Padi di Daerah Aliran Sungai Bengawan Solo Kabupaten Bojonegoro Provinsi Jawa Timur. Tesis. Sekolah Pascasarjana. Institut Pertanian Bogor. Program Magister Sains Agribisnis. Bogor.

Asche, F. and R. Tveteras. 1999. Modeling Production Risk with A Two-Step Procedures. Journal of Agricultural and Resource Economics. Vol 24(2): 424-439.

Badan Pusat Statistik (BPS). 2016a. Produk Domestik Bruto atas Dasar Harga Konstan 2010 Menurut Lapangan Usaha tahun 2000 - 2015. http:// bps.go.id/linkTabelStatis/view/id/1252. (Diakses tanggal 29 September 2016).

Badan Pusat Statistik (BPS). 2016b. Produksi Perikanan menurut Subsektor tahun 1999 - 2014. http:// www.bps.go.id/linkTabelStatis/view/id/1711. (Diakses tanggal 29 September 2016).
Cooper, D.R. dan C.W. Emory. 1996. Metode Penelitian Bisnis Jilid 1. Jakarta (ID): Erlangga.

Central Proteinaprima. 2013. Standard Operating Procedures (SOP) Budi daya Udang Litopenaeus Vannamei. CPP Surabaya Operation PT. Central Proteinaprima, Tbk. Surabaya.

Cruz-Lacierda E.R., L.D. de la Pena and S.C Lumanlan-Mayo. 2000. The Use of Chemicals in Aquaculture in Philippines. Southeast Asian Fisheries Development Center, Aquaculture Department, Phillippines.

Diatin, I., S. Arifianty dan N. Farmayanti. 2008. Optimalisasi Input Produksi pada Kegiatan Budi daya Udang Vaname (Litopenaeus vannamei): Studi Kasus pada UD Jasa Hasil Diri di Desa Lamaran Tarung, Kecamatan Cantigi, Kabupaten Indramayu. Jurnal Akuakultur Indonesia. Vol 7(1): 39-49.

Divisi Marketing Global Shrimp Feed. 2016a. Produksi Udang Vannamei di Kecamatan Blanakan Periode Januari 2013 hingga Januari 2016. PT. Universal Agri Bisnisindo. Bekasi.

Divisi Marketing Global Shrimp Feed. 2016b. Mortality Rate Udang Vannamei di Kecamatan Blanakan. PT. Universal Agri Bisnisindo. Bekasi

Fanani, A. 2015. Pengaruh Kemitraan terhadap Risiko Usahatani Tembakau di Kabupaten Bojonegoro Provinsi Jawa Timur. Tesis. Sekolah Pascasarjana. Institut Pertanian Bogor. Program Magister IImu Ekonomi Pertanian. Bogor.

Fariyanti, A. 2008. Perilaku Ekonomi Rumah tangga Petani Sayuran dalam Menghadapi Risiko Produksi dan Harga Produk di Kecamatan Pangalengan Kabupaten Bandung. Disertasi. Sekolah Pascasarjana. Institut Pertanian Bogor. Program Doktor IImu Ekonomi Pertanian. Bogor.

Hartoyo, K.L. 2017. Analisis Risiko Produksi Udang Vannamei (Litopenaeus vannamei) di Kecamatan Blanakan Kabupaten Subang Provinsi Jawa Barat. Skripsi. Fakultas Ekonomi dan Manajemen. Institut Pertanian Bogor. Program Studi Agribisnis. Bogor.

Just, R.E. and R.D. Pope. 1976. On the Relationship of Input Decisions and Risk. California Agricultural Experiment Station. University of California.

Kementerian Kelautan dan Perikanan. 2012. Laporan Akuntabilitas Kinerja Kementerian Kelautan dan Perikanan Tahun 2012. Jakarta.

Kementerian Kelautan dan Perikanan. 2016a. PDB Perikanan 2011-2015. Sistem Informasi Diseminasi Data dan Statistik (SIDATIK). Jakarta.

Kementerian Kelautan dan Perikanan. 2016b. Konsumsi Ikan 2011-2015. Sistem Informasi Diseminasi Data dan Statistik. Jakarta. 
Kementerian Kelautan dan Perikanan. 2017. Sepuluh Provinsi Produsen Utama Udang Vannamei di Indonesia Tahun 2010-2015. Direktorat Jenderal Perikanan Budi Daya. Jakarta.

Kharisma, A. dan A. Manan. 2012. Kelimpahan Bakteri Vibrio sp. pada Air Pembesaran Udang Vannamei (Litopenaeus vannamei) sebagai Deteksi Dini Serangan Penyakit Vibriosis. Jurnal IImiah Perikanan dan Kelautan. Vol 4(2): 129-134.

Leung, P., L.T. Tran and A.W. Fast. 2000. A Logistic Regression of Risk Factors for Disease Occurrence of Asian Shrimp Farms. Disease of Aquatic Organisms Journal. 41(1):65-76.

Mustafa, A. dan E. Ratnawati. 2007. Faktor-Faktor Dominan yang Mempengaruhi Produktivitas Tambak di Kabupaten Pinrang Sulawesi Selatan. Jurnal Riset Akuakultur. Vol 2(1): 117-133.

Mustafa, A., I. Sapo dan M. Paena. 2010. Studi Penggunaan Produk Kimia dan Biologi pada Budi daya Udang Vaname (Litopenaeus vannamei) di Tambak Kabupaten Pesawaran Provinsi Lampung. Jurnal Riset Akuakultur. 5(1):115-133.

Ruiz-Velazco J.M.J., A. Hernandez-Llamas, V.M. Gomez-Munoz and F.J. Magallon. 2010. Dynamics of Intensive Production of Shrimp Litopenaeus vannamei Affected by White Spot Disease. Journal of Aquaculture. 300(4):113-119.

Sanchez-Zazueta, E. and F.J. Martinez-Cordero. 2009. Economic Risk Assessment of A Semi-Intensive Shrimp Farm in Sinaloa Mexico. Journal of Aquaculture Economics and Management. 13(4):312-327.

Saptana. 2011. Efisiensi Produksi dan Perilaku Petani terhadap Risiko Produktivitas Cabai Merah di provinsi Jawa Tengah. Disertasi. Sekolah Pascasarjana. Institut Pertanian Bogor. Program Doktor Ilmu Ekonomi Pertanian. Bogor.

Susilo, H. 2007. Analisis Ekonomi Usaha Budi daya Tambak dan Faktor-Faktor yang Mepengaruhi Produksi. Jurnal Ekonomi Pertanian dan Pembangunan. 4(2):19-23.

Tempo. 2014. Petambak Udang Subang Rugi Miliaran Akibat Banjir. http://bisnis.tempo.co/read/547372/ petambak-udang-subang-rugi-miliaran-akibat-banjir. diakses tanggal 24 Desember 2017.

Umiliana, M., Sarjito dan Desrina. 2016. Pengaruh Salinitas terhadap Infeksi Infectious myonecrosis virus (IMNV) pada Udang Vaname Litopenaeus vannamei (Boone, 1931). Journal of Aquaculture Management and Technology. 5(1):73-81.

Vinanda, G. 2016. Risiko Produksi dan Risiko Harga Ayama Broiler serta Preferensi Peternak di Kabupaten Bekasi. Tesis. Sekolah Pascasarjana. Institut Pertanian Bogor. Program Magister IImu Ekonomi Pertanian. Bogor.
Walter, J.T., R.K. Roberts, J.A. Larson, B.C. English and D.D. Howard. 2004. Effects of Risk, Disease, and Nitrogen Source on Optimal Nitrogen Fertilization Rates in Winter Wheat Production [Working Paper]. Oklahoma. Southern Agricultural Economic Association. 